\title{
Quality characteristics of cookies with acaiberry (Euterpe oleracea Mart.) powder added
}

\author{
Young-Sim Choi ${ }^{1 *}$, Sun-Kyung Kim ${ }^{2}$, Eun-Kyoung $\mathrm{Mo}^{3}$ \\ ${ }^{1}$ Department of Food and Culinary Art, Suwon Women's University, Suwon 441-748, Korea \\ ${ }^{2}$ Department of Baking Design, Sorabol College, Gyeongju 780-711, Korea \\ ${ }^{3}$ Research and Development Center, DBIO Incorporation, Daejeon 305-764, Korea \\ 아사이베리 분말을 첨가한 쿠키의 품질 특성 \\ 최영심 ${ }^{1 *} \cdot$ 김선경 ${ }^{2} \cdot$ 모은경 ${ }^{3}$ \\ ${ }^{1}$ 수원여자대학교 식품조리과, ${ }^{2}$ 서라벌대학 베이킹디자인과, ${ }^{3}$ (주) 대덕바이오
}

\begin{abstract}
The quality characteristics of cookies with $0 \%, 2 \%, 4 \%, 6 \%$, and $8 \%$ acaibery (Euterpe oleracea Mart) powder added were analyzed through chemical and sensory evaluations. The moisture contents of the cookies were insignificant $(\mathrm{p}<0.05)$ as the acaiberry powder levels $(0 \%, 2 \%, 4 \%, 6 \%$, and $8 \%)$ increased. The $\mathrm{pH}$ values of the cookies were significantly reduced in all the acaibeny powder groups compared to the controls. According to the Hunter color of the cookies, tbe L-value (lightness) and the b-value (yellowness) significantly decreased $(\mathbf{p}<\mathbf{0 . 0 5})$, whereas the a-value (redness) increased when the acaiberry powder was added at different levels $(0 \%, 2 \%, 4 \%, 6 \%$, and $8 \%)$. The spread factor decreased significantly $(\mathrm{p}<0.05)$ with the acaiberry powder addition levels $(0 \%, 2 \%, 4 \%, 6 \%$, and $8 \%)$. The hardness of the cookies significantly decreased $(p<0.05)$ according to the increase in the acaiberry powder level $(0 \%, 2 \%, 4 \%, 6 \%$, and $8 \%)$. The sensory evaluation of the cookies showed that those with $6 \%$ acaiberry powder added had the greatest of the color, taste, flavor, texture, and overall acceptability. These results showed that up to $6 \%$ acaibery powder can be added to cookies.
\end{abstract}

Key words : cookies, euterpe oleracea, quality, sensory, overall acceptability

\section{서 론}

최근에는 경제발전 더불어 의학기술의 발달로 인해 인간 의 평균수명이 늘어나면서 건강하게 삶을 보내고자 하는 욕구가 증가하고 있다(1). 따라서 현대인들은 건강을 유지 하기 위해 건강 기능성 식품에 관심을 기울이고 있으며 실제로 건강 관련 식품을 섭취하고 있는 인구도 늘어나고 있는 추세에 있다고 알려져 있다(2,3). 특히 항산화 식품에 대한 관심이 증가하고 있는데 이러한 항산화물질은 활성산 소에 의한 산화 및 염증이 각종 질환과 관련이 있다는 사실 이 속속 밝혀지면서 천연물이나 각종 과실류에서 항산화 및 항염증과 관련된 기능성 성분을 함유한 식품에 대한

*Corresponding author. E-mail : yschoi@swc.ac.kr Phone : 82-31-290-8930, Fax : 82-31-290-8924
관심이 고조되고 있다(4).

과실 중 하나인 나무 딸기류(berry)에는 적자색을 띄는 안토시아닌 색소가 다량 함유되어 있는데, 안토시아닌 색 소는 식물계에 널리 분포되어 있는 페놀화합물 중의 하나로 수용성 색소로 알려져 있다(5).

이러한 안토시아닌의 생리활성 기능이 항산화 작용에 뛰어나다고 보고됨에 따라(6), 여러 가지 나무 딸기류에 대한 기능적 효과에 대한 관심이 증가하고 있으며 특히 우리나라에서는 블루베리, 딸기, 복분자 등이 주로 소비되 고 있다(7). 아직 우리나라에 대중화 되지 않은 아사이베리 는 베리류 과일의 하나로 기능적 우수성이 점차 알려져 일부가 상품화 되어 판매되고 있으나 국내에서 생산이 어렵 고 높은 가격 때문에 일부 기능성 식품에 관심 있는 사람들 만 이용하고 있다(8).

아사이베리(Acaiberry, Euterpe oleracea Mart.)는 아마존 
의 보랏빛 진주로 널리 알려져 있으며, 열매 모양은 둥글고 진한 보라색을 띄고 있다. 또한 포도와 모양이 비슷하고 탄탄한 과육이 씨를 감싸고 있으며, 직경은 $1 \sim 1.4 \mathrm{~cm}$ 로 블루베리보다 약간 큰 형태이다 $(9,10)$.

아사이베리가 함유하는 안토시아닌과 폴리페놀의 뛰어 난 항산화력은 노화방지 뿐만 아니라 심장질환을 예방하 고, 시력회복과 암 예방 및 소화기능을 개선하고 다이어트 에 효과적으로 알려져 있다(11). 또한 콜레스테롤 수치를 감소하며 신장과 간 및 위의 기능을 향상시켜주고, 혈류 개선 등에 도움을 주고, 이외에도 머리를 맑게 해주고 정신 관련 질병에도 도움이 되는 효과를 나타내는 것으로 보고되 어 있다(12). 또한 아사이베리에는 필수아미노산을 모두 함유하고 있고, 단백질 합성에 필요한 비필수아미노산도 포함하고 있으며 비타민 $\left(\mathrm{A}, \mathrm{B}_{1}, \mathrm{C}, \mathrm{E}\right)$, 칼숨, 인, 철분, 필수지 방산 등의 필수 영양분을 고루 함유하고 있어 기능성 식품 으로 각광받고 있다(13).

그러나 아사이베리는 단맛이 없고 특유의 맛과 향이 없 어 과일 자체로 먹기보다는 기능적 효과를 얻기 위해서는 다른 과일들과 혼합하여 음료로 만들어 섭취하거나 아사이 베리를 수확한 후 바로 냉동 및 동결 건조하여 분말로 가공 한 것을 사용하는 것이 기능적으로 우수하다고 하였다(14). 수확 후 상하기 쉬운 아사이베리를 가공하여 분말로 만들어 다른 식품에 첨가하여 섭취하고 있으며 $(8,11)$, 특히 북미나 유럽에서 dietary supplement로 인정받아 tablet, juice, energy drink, smoothie 등의 형태로 애용되고 있다(12).

소비자의 식품에 대한 기호가 다양해지고 고급화를 추구 하는 경향과 더불어 웰빙에 관한 관심의 증대로 인해 기능 성 재료를 이용한 제품 개발에 관심이 고조되고 있다(15). 이에 따라 제과제빵 분야에서도 소비자의 기호를 맞추기 위해 제품에 영양적인 가치 외에 기능적인 효과가 기대되는 여러 가지 부재료를 첨가한 다양한 제품 개발의 연구가 이루어지고 있다(16-18).

제과제빵 제품에서도 글루텐 함량에 큰 영향을 받지 않 아 때문에 다양한 부재료에 따라 제조하기 간편한 머핀(8, 19), 나무 딸기류를 가공하여 첨가 제조한 쿠키(20), 딸기 스폰지 케이크(21), 복분자 젤리(22), 복분자 푸딩(23) 등이 이루어졌다. 또한 기능성 재료를 첨가한 쿠키의 경우 오디 쿠키(24), 구기자 쿠키(25), 비트 쿠키(26), 자색고구마 쿠키 (27), 삼백초 분말 쿠키(28), 구아바 분말 쿠키(29), 산수유 분말 쿠키(30), 블루베리 분말 쿠키(31) 등의 연구가 진행되 었다.

이외에도 최근 아사이베리를 첨가한 식품의 경우에는 면류(32), 주악(33), 과편(34) 등의 연구가 이루어졌고, 이외 에 미백효과 및 작용기전 연구(35) 보고되었다. 그러나 아사 이베리에 대한 연구가 아직 미비한 실정이므로 아사이베리 를 좀 더 다양한 제품으로의 이용도를 높이고 식품 첨가 부재료로 폭넓게 사용할 수 있도록 다용도의 식품 개발이
요구되는 실정이다.

따라서 본 연구는 최근 건강에 대한 관심의 고조로 인해 아사이베리에 대한 관심이 증가되고 있어 다양한 생리적 효능과 영양학적 특성이 우수한 아사이베리의 실제적인 활용방안을 모색하기 위한 일환으로 기능성 효과를 가진 아사이베리 분말을 $0 \%, 2 \%, 4 \%, 6 \%, 8 \%$ 배합비율로 첨가 하여 쿠키를 제조한 후 품질 특성을 살펴보고 최적의 첨가 량을 살펴보고자 하였다.

\section{재료 및 방법}

\section{실험재료}

본 연구에서 사용된 아사이베리 분말(Freeze Dried Acai Powder)은 2013년 라온네이처에서 구입하여 사용하였다. 밀가루는 시판하는 박력분(제일제 당)을 구입하여 사용하 였으며 버터(웰가 롯데), 쇼트닝(웰가 코코쇼트닝), 설탕(백 설), 소금(한주소금), 물엿(오뚜기 옛날 물엿), 달걀(풀무원), 바닐라 향(성진식품)을 구입하여 사용하였다.

\section{쿠키의 제조}

쿠키의 제조는 선행 연구(36)를 참고하여 예비실험 한 후 수정 - 보완하였다. 아사이베리 분말 쿠키 배합비는 Table 1과 같으며 예비실험을 통해 맛의 평가가 불가능한 $10 \%$ 이상의 첨가군을 제외하고 아사이베리 분말을 $0 \%$, $2 \%, 4 \%, 6 \%, 8 \%$ 를 첨가하여 쿠키를 제조하였다. 쿠키 제조방법은 반죽기(Kitchen Aid 5K5SS, USA)에 버터와 쇼 트닝을 넣고 중속으로 1 분간 믹싱한 후 설탕, 물엿, 소금을 넣고 고속으로 2 분간 믹싱한 다음 전란과 난황을 넣고 5 분 간 크리밍 한 후 박력분, 아사이베리 분말, 바닐라 향을 넣고 1 단에서 20 초간 혼합하였다. 혼합된 반죽을 밀봉하여 냉장고에서 1 시간 휴지한 후 밀대로 $1 \mathrm{~cm}$ 두께를 밀어 원형 틀 $5.5 \mathrm{~cm}$ 성형하여 오븐(Hanyoung HPO-3003, Korea)에 넣 고 윗불 $190{ }^{\circ} \mathrm{C}$, 아랫불 $160{ }^{\circ} \mathrm{C}$ 로 16 분간 구워 완성하였다. 오븐에서 다 구워진 쿠키는 1시간동안 실온에서 냉각시킨 후 연구에 사용하였다.

\section{수분함량 및 $\mathrm{pH}$ 측정}

수분함량 측정은 적외선 수분 측정기(FD-240, Japan)를 사 용하여 $3 \mathrm{~g}$ 의 아사이베리 분말 쿠키를 아사이베리 분말 첨가 량에 따라 각각 3회 반복 측정하여 평균값으로 구하였다.

쿠키의 $\mathrm{pH}$ 측정은 각 시료 $5 \mathrm{~g}$ 을 증류수 $45 \mathrm{~mL}$ 에 충분히 균질화 시킨 후 여과한 후 $\mathrm{pH} \operatorname{meter}(340, \mathrm{UK})$ 로 각각 3회 반복 측정하여 평균값으로 나타냈다.

\section{퍼짐성 지수 측정}

퍼짐성 지수 측정은 $\mathrm{AACC}$ method $10-50 \mathrm{D}(37)$ 의 방법에 
Table 1. Ingredients of acaiberry (Euterpe oleracea Mart.) powder cookies

(g)

\begin{tabular}{lrrrrr}
\hline \multirow{2}{*}{ Ingredients } & \multicolumn{5}{c}{ Acaiberry powder } \\
\cline { 2 - 6 } & $0 \%$ & $2 \%$ & $4 \%$ & $6 \%$ & $8 \%$ \\
\hline Wheat flour & 400 & 392 & 384 & 376 & 368 \\
Acaiberry (Euterpe oleracea Mart.) & 0 & 8 & 16 & 24 & 32 \\
Butter & 132 & 132 & 132 & 132 & 132 \\
Shortening & 132 & 132 & 132 & 132 & 132 \\
Sugar & 140 & 140 & 140 & 140 & 140 \\
Salt & 4 & 4 & 4 & 4 & 4 \\
Dextrose syrup & 20 & 20 & 20 & 20 & 20 \\
Egg & 40 & 40 & 40 & 40 & 40 \\
Egg Yolk & 40 & 40 & 40 & 40 & 40 \\
Vanilla essence & 2 & 2 & 2 & 2 & 2 \\
\hline
\end{tabular}

의해 쿠키의 직경과 두께를 다음과 같이 측정 하였다. 쿠키 6 개를 수평으로 정렬하고 총 길이를 측정하여 그 값을 6 으 로 나누어 쿠키의 직경을 구하고 이러한 방법으로 반복 측정하여 평균값으로 하였다. 쿠키 6개를 수직으로 쌓아 올린 다음 그 높이를 측정한 다음 6 으로 나누어 쿠키의 두께를 구하고 동일한 방법으로 반복 측정하여 평균값으로 하였다.

\section{Spread Factor $=\frac{\text { Average width of } 1 \text { cookies }(\mathrm{cm})}{\text { Average thickness of } 1 \text { cookies }(\mathrm{cm})}$}

색도 측정

색도 측정은 색차계(Color meter JX-777, Minolta, Japan) 를 이용하여 먼저 표준백판(L: $+98.46, \mathrm{a}:-0.23, \mathrm{~b}:+1.02)$ 로 보정한 후 사용하였다. 측정 방법은 아사이베리 분말 쿠키 의 윗부분을 각각 3 회 반복 측정하여 평균값으로 명도, 적색 도, 황색도를 구하였다.

\section{경도 측정}

경도 측정은 Texture analyser(TA-XT Plus Stable Micro System, England)를 사용하였고 측정 조건은 다음과 같다. 측정조건은 pre test speed $2 \mathrm{~mm} / \mathrm{s}$, test speeed $0.5 \mathrm{~mm} / \mathrm{s}$, post test speed $10.0 \mathrm{~mm} / \mathrm{s}$, strain $50 \%$, trigger type auto $5 \mathrm{~g}$ 이다. 이 때 $2 \mathrm{~mm}$ cylinder probe로 아사이분말 쿠키의 윗부분을 각각 3회 반복 측정하여 평균값으로 구하였다.

\section{관능 검사}

관능검사는 식품 전공 대학생 20명(평균연령: 25.4세)을 대상으로 본 연구의 목적과 평가 문항에 대해 사전에 설명 한 후에 실시하였다. 동일한 흰색 접시에 쿠키 1 개씩 담아서
시료를 제공하였고 각각의 시료를 평가한 후 물로 입안을 헹궈 가면서 쿠키의 색깔, 맛, 향기, 텍스쳐, 전체적인 기호 도 등을 평가하도록 하였다. 각 문항의 평가는 7점 척도법으 로 실시하였고, 평가점수 1점은 '매우 싫어함', 7점은 ‘매 우 좋아함'으로 하였다.

\section{통계 처리}

SPSS 12.0 program(SPSS Inc., Chicago, IL, USA)으로 평균과 표준편차를 구하고 ANOVA test를 실시한 후 사후 검증을 $\mathrm{p}<0.05$ 에서 Duncan's multiple range test로 하여 유의 적인 차이를 살펴보았다. 또, 쿠키의 특성과 관능 특성에 대해 Pearson's correlation coefficient를 구한 후 상관관계를 분석하였다.

\section{결과 및 고찰}

\section{수분함량 및 $\mathrm{pH}$}

아사이베리 분말 쿠키의 수분함량을 측정한 결과 Table 2 와 같다. 아사이베리 분말 쿠키의 수분함량은 대조군에서 $7.16 \pm 0.14 \%$ 이고, 아사이베리 분말 $8 \%$ 첨가 쿠키의 경우는 $7.26 \pm 0.05 \%$ 로 나타났다. 아사이베리 분말의 첨가량이 증가 함에 따라 수분함량은 증가하는 경향을 보였으나 유의적인 차이는 나타나지 않았다 $(\mathrm{p}<0.05)$. 따라서 아사이베리 분말 쿠키의 수분함량은 아사이베리 분말에 직접적인 영향을 받지 않는 것으로 사료된다.

삼백초 분말 슈거 스냅 쿠키의 연구(28)의 연구에서도 수분함량에 있어서 유의적인 차이를 보이지 않았으며 쿠키 의 수분함량이 $10 \%$ 이하라고 보고하였다. 또, 아사이베리 를 첨가한 머핀(8)의 연구에서는 머핀의 수분함량은 대조군 이 $25.94 \%$ 이며 아사이베리 첨가량이 증가함에 따라 머핀의 수분함량이 증가하는 경향을 보여 본 연구와 차이를 보였 다. 이는 본 연구의 쿠키보다 머핀의 경우가 수분 함량이 많은 것은 첨가되는 기타 부재료의 차이에 의한 것이라고 사료된다.

아사이베리 분말 쿠키의 $\mathrm{pH}$ 측정 결과 대조군의 경우 $6.58 \pm 0.10$ 이고, 아사이베리 분말 $8 \%$ 첨가 쿠키의 $\mathrm{pH}$ 는 $5.65 \pm 0.05$ 로 나타나 아사이베리 분말의 첨가량이 증가함에 따라 $\mathrm{pH}$ 는 유의적으로 낮아지는 경향을 보였다 $(\mathrm{p}<0.05)$ 딸기 분말을 첨가한 쿠키(16)의 연구에서도 딸기 분말의 첨가량이 증가함에 따라 $\mathrm{pH}$ 가 유의적으로 감소하는 것으 로 나타나 본 연구와 유사한 경향을 보였다. 이는 딸기 분말 에 함유된 유기산에 의한 것이라고 밝혔으며, 베리류의 하 나인 아사이베리 분말도 함유된 유기산과 당의 변화로 인해 $\mathrm{pH}$ 에 영향을 미친 것으로 사료된다.

퍼짐성 지수

아사이베리 분말 쿠키의 직경과 두께, 퍼짐성을 살펴 본 
Table 2. The moisture contents and $\mathrm{pH}$ of cookies added with acaiberry (Euterpe oleracea Mart.) powder

\begin{tabular}{ccc}
\hline Acaiberry & Moisture contents $(\%)$ & $\mathrm{pH}$ \\
\hline $0 \%$ & $7.16 \pm 0.14^{\mathrm{NS} 12)}$ & $6.58 \pm 0.10^{\mathrm{a}}$ \\
$2 \%$ & $7.18 \pm 0.11^{\mathrm{NS}}$ & $6.24 \pm 0.01^{\mathrm{b}}$ \\
$4 \%$ & $7.24 \pm 0.15^{\mathrm{NS}}$ & $6.03 \pm 0.02^{\mathrm{c}}$ \\
$6 \%$ & $7.21 \pm 0.14^{\mathrm{NS}}$ & $5.92 \pm 0.01^{\mathrm{d}}$ \\
$8 \%$ & $7.26 \pm 0.05^{\mathrm{NS}}$ & $5.65 \pm 0.05^{\mathrm{e}}$ \\
\hline
\end{tabular}

${ }^{1)}$ Values are mean $\pm \mathrm{SD}$

${ }^{27}$ The same superscripts in a column are not significantly different each other at $p<0.05$ NS: not significant

결과 Table 3과 같다. 쿠키의 직경과 퍼짐성은 일반적으로 직경 또는 퍼짐성이 큰 쿠키가 바람직한 쿠키로 보고되고 있으며 이는 밀가루의 품질을 알 수 있는 지표로 사용되어 진다.

아사이베리 분말 쿠키의 직경은 대조군의 경우 $6.18 \pm 0.01 \mathrm{~cm}$ 이고, 아사이베리 분말 $8 \%$ 첨가 쿠키의 경우 가 $5.83 \pm 0.12 \mathrm{~cm}$ 의 너비로 나타났다. 또한 아사이베리 분말 의 첨가량이 증가함에 따라 너비는 유의적으로 감소하는 경향을 보였다 $(\mathrm{p}<0.05)$.

아사이베리 분말 쿠키의 두께는 대조군의 경우 $1.08 \pm 0.09 \mathrm{~cm}$ 이고 아사이베리 분말 $8 \%$ 첨가 쿠키의 경우가 $1.48 \pm 0.02 \mathrm{~cm}$ 로 나타났다. 아사이베리 분말 첨가량에 따른 두께를 살펴보면 대조군과 아사이베리 분말 $2 \%$ 첨가 쿠키 간에는 유의적인 차이를 보이지 않았으며 아사이베리 분말 $4 \%$ 이상을 첨가한 경우가 대조군과 유의적인 차이를 보였 다 $(\mathrm{p}<0.05)$.

퍼짐성 지수는 쿠키 품질에서 관능적 요인과 함께 중요 한 평가 항목으로 쿠키를 오븐에서 구울 때 반죽이 바깥쪽 으로 퍼지면서 두께는 얇아지고 직경이 커지는 것으로 반죽 시간과 방법에 의한 반죽의 점성 상태, 재료, 밀가루의 수분 흡수율 등이 영향을 미치는 것으로 보고되었다(26).

아사이베리 분말 쿠키의 퍼짐성 지수는 대조군의 경우가 $5.69 \pm 0.09$ 로 가장 큰 값을 보였으며 아사이베리 분말 $8 \%$ 첨가 쿠키의 경우가 $3.94 \pm 0.07$ 로 가장 작은 값을 보였다.

또한 아사이베리 분말 첨가량에 따라 퍼짐성은 유의적으 로 감소하는 경향을 보였다 $(\mathrm{p}<0.05)$. 삼백초 분말 슈거 스 냅 쿠키(28), 비트 가루 쿠키(26), 산수유 분말 쿠키(30) 연구 에서는 부재료의 첨가량이 증가함에 따라 퍼짐성 지수가 유의적으로 감소하는 경향을 보여 본 연구와 유사한 경향을 보였다.

반면 딸기 분말 쿠키 연구(20)에서는 딸기 분말의 첨가량 이 증가함에 따라 쿠키의 퍼짐성 지수가 유의적으로 증가하 는 경향이 나타났고, 이는 딸기 분말의 첨가량이 증가함에 따라 유의적으로 수분함량이 증가하는 경향을 보여 이에 영향을 받아 퍼짐성이 커졌다고 보고하였다.
Table 3. The spread factor of cookies added with acaiberry (Euterpe oleracea Mart.) powder

\begin{tabular}{cccc}
\hline Acaiberry & Widthness (cm) & Thickness (cm) & Spread factor \\
\hline $0 \%$ & $6.18 \pm 0.01^{\mathrm{a} 112)}$ & $1.08 \pm 0.09^{\mathrm{d}}$ & $5.69 \pm 0.09^{\mathrm{a}}$ \\
$2 \%$ & $6.13 \pm 0.02^{\mathrm{b}}$ & $1.12 \pm 0.03^{\mathrm{d}}$ & $5.42 \pm 0.18^{\mathrm{b}}$ \\
$4 \%$ & $6.00 \pm 0.00^{\mathrm{c}}$ & $1.24 \pm 0.04^{\mathrm{c}}$ & $4.82 \pm 0.18^{\mathrm{c}}$ \\
$6 \%$ & $5.94 \pm 0.43^{\mathrm{d}}$ & $1.39 \pm 0.03^{\mathrm{b}}$ & $4.26 \pm 0.09^{\mathrm{d}}$ \\
$8 \%$ & $5.83 \pm 0.12^{\mathrm{e}}$ & $1.48 \pm 0.02^{\mathrm{a}}$ & $3.94 \pm 0.07^{\mathrm{e}}$ \\
\hline
\end{tabular}

${ }^{1)}$ Values are mean \pm SD

${ }^{2)}$ The same superscripts in a column are not significantly different each other at $p<0.05$

색 도

아사이베리 분말 쿠키의 색도를 살펴보면 Table 4와 같 다. 명도의 경우 아사이베리 분말 쿠키의 대조군에 있어서 $77.30 \pm 0.52$ 로 나타났고, 아사이베리 분말 $8 \%$ 첨가 쿠키의 경우 $52.00 \pm 0.65$ 를 보였다. 대조군에 비해 아사이베리 분말 을 첨가할수록 명도는 유의적으로 감소하는 경향을 보였 고, 아사이베리 분말 $2 \% \sim 6 \%$ 첨가한 쿠키 간에는 유의적인 차이를 보이지 않았다 $(\mathrm{p}<0.05)$. 아사이베리 퓨레를 첨가한 국수(32), 아사이베리 분말을 첨가한 머핀(8), 아사이베리 퓨레와 분말을 첨가한 주악(33) 연구에서 첨가량이 증가함 에 따라 명도가 유의적으로 감소하는 경향을 보여 본 연구 와 유사한 경향을 보였다.

적색도의 경우 아사이베리 분말 $8 \%$ 첨가 쿠키는 $0.90 \pm 0.10$ 으로 가장 큰 값을 보였고, 아사이베리 분말 쿠키 대조군은 $-4.93 \pm 0.75$ 로 가장 적은 값을 보였다. 아사이베리 분말 첨가량이 증가함에 따라 적색도가 증가하는 경향을 나타냈고 아사이베리 분말 쿠키 대조군과 비교하였을 때 아사이베리 분말 $2 \%$ 첨가 쿠키는 유의적인 차이가 없었고, 아사이베리 분말 $4 \%$ 이상 첨가한 쿠키는 대조군과 유의적 인 차이를 보였다 $(\mathrm{p}<0.05)$. 아사이베리 분말 머핀 $(8)$, 아사 이베리 퓨레와 분말을 첨가한 주악(33), 아사이베리 퓨레 국수(32) 연구에서 첨가량이 증가함에 따라 적색도가 유의 적으로 증가하는 경향을 보여 본 연구와 유사한 경향을 보였다.

황색도의 경우 아사이베리 분말 쿠키의 대조군은 $40.50 \pm 0.45$ 로 가장 높게 나타났고 아사이베리 분말 $8 \%$ 첨 가 쿠키의 경우는 $20.46 \pm 0.45$ 로 가장 낮은 값을 보였다. 아사이베리 분말 첨가량이 증가함에 따라 황색도가 감소하 는 경향을 보였으며 아사이베리 분말 $6 \%$ 와 $8 \%$ 첨가 쿠키 간에는 유의적인 차이가 나타나지 않았다 $(\mathrm{p}<0.05)$.

아사이베리 퓨레를 첨가한 국수 (32), 아사이베리 분말 머핀(8), 아사이베리 퓨레와 분말을 첨가한 주악(33) 연구에 서 첨가량이 증가함에 따라 황색도가 유의적으로 감소하는 경향을 보여 본 연구와 유사한 경향을 보였다.

그 외에 삼백초 분말 슈거 스냅 쿠키(28), 블루베리 쿠키 (31), 딸기 분말 쿠키(20), 자색 고구마 가루 쿠키(27) 연구에 
Table 4. The Hunter's value of cookies added with acaiberry (Euterpe oleracea Mart.) powder

\begin{tabular}{cccc}
\hline Acaiberry & L-value & a-value & b-value \\
\hline $0 \%$ & $77.30 \pm 0.52^{\mathrm{a} 1122)}$ & $-4.93 \pm 0.75^{\mathrm{c}}$ & $40.50 \pm 0.45^{\mathrm{a}}$ \\
$2 \%$ & $65.80 \pm 0.78^{\mathrm{b}}$ & $-0.46 \pm 0.32^{\mathrm{b}}$ & $33.80 \pm 0.95^{\mathrm{b}}$ \\
$4 \%$ & $58.40 \pm 1.17^{\mathrm{b}}$ & $0.43 \pm 0.66^{\mathrm{a}}$ & $28.00 \pm 1.44^{\mathrm{c}}$ \\
$6 \%$ & $56.83 \pm 0.05^{\mathrm{b}}$ & $0.63 \pm 0.11^{\mathrm{a}}$ & $21.93 \pm 0.55^{\mathrm{d}}$ \\
$8 \%$ & $52.00 \pm 0.65^{\mathrm{c}}$ & $0.90 \pm 0.10^{\mathrm{a}}$ & $20.46 \pm 0.45^{\mathrm{d}}$ \\
\hline
\end{tabular}

${ }^{1)}$ Values are mean \pm SD

${ }^{2}$ The same superscripts in a column are not significantly different each other at $p<0.05$

서도 분말 부재료의 첨가량이 증가함에 따라 유의적으로 명도와 황색도는 감소하고 적색도는 증가하는 경향을 보여 첨가량이 본 연구의 결과와 유사하였다. 반면 산수유 분말 쿠키 연구(30)의 경우는 산수유의 붉은 과피와 노란색의 과육으로 인해 산수유 분말 첨가량이 증가함에 따라 황색도 가 증가한 것으로 보고하여 본 연구와 차이를 보였다.

본 연구에 사용된 아사이베리 분말은 붉은색을 띄고 있 어 자체의 색이 아사이베리 분말 쿠키의 색도에 영향을 주어 명도와 황색도는 각각 감소하였고, 적색도는 증가하 는 경향을 보였다.

\section{경 도}

아사이베리 분말 쿠키의 경도를 측정한 결과는 Table 5 와 같다. 아사이베리 분말 쿠키의 대조군의 경우 $1253.40 \pm 61.72$ 로 가장 낮은 값을 보였고 아사이베리 분말 $8 \%$ 첨가 쿠키의 경우 $2306.92 \pm 77.32$ 로 가장 큰 값을 보였 다. 아사이베리 분말의 첨가량이 증가함에 따라 경도의 값 이 유의적으로 증가하는 경향을 보였으며, 아사이베리 분 말 $4 \%$ 와 $6 \%$ 첨가 쿠키간에는 경도가 유의적으로 차이를 보이지 않았다( $\mathrm{p}<0.05)$. 아사이베리 퓨레 첨가 국수 연구 (32), 아사이베리 주악 연구(33)에서 첨가량이 증가함에 따 라 경도가 유의적으로 증가하는 경향을 보여 본 연구와 유사한 경향을 보였다.

또, 삼백초 분말 슈거 스냅 쿠키(28), 비트 가루 쿠키(26), 블루베리 쿠키(31) 연구에서는 부재료 첨가량이 증가함에 따라 경도가 증가하는 경향을 보여 본 연구와 유사한 경향 을 보였다. 반면 아사이베리 머핀 연구(8), 딸기 분말을 첨가 한 쿠키(20), 산수유 분말 쿠키(30)의 연구에서는 부재료의 첨가량이 증가함에 따라 경도가 감소하는 경향을 보였다. 이러한 차이는 부재료의 특성과 수분함량, air cell의 상태, 비중 등에 따라 경도에 영향을 미친다는 연구 $(25,26)$ 가 보고 되었으며, 이러한 특성이 쿠키의 경도에 영향을 미치는 것 으로 알려져 있다(20).

\section{관능검사}

아사이베리 분말 쿠키의 관능 평가 결과는 Table 6 과
Table 5. The hardness of cookies added with acaiberry (Euterpe oleracea Mart.) powder

\begin{tabular}{cc}
\hline Acaiberry & Hardness \\
\hline $0 \%$ & $1253.40 \pm 61.72^{\mathrm{d} 112)}$ \\
$2 \%$ & $1585.09 \pm 17.86^{\mathrm{c}}$ \\
$4 \%$ & $1856.66 \pm 32.92^{\mathrm{b}}$ \\
$6 \%$ & $1958.57 \pm 52.49^{\mathrm{b}}$ \\
$8 \%$ & $2306.92 \pm 77.32^{\mathrm{a}}$ \\
\hline${ }^{1)}$ Values are mean $\pm \mathrm{SD}$ \\
The same superscripts in a column are not significantly different each other at \\
p<0.05
\end{tabular}

같다. 아사이베리 분말 쿠키의 색깔(color)의 경우는 대조군 이 $4.07 \pm 0.59$ 점으로 평가되었고, 아사이베리 분말 $6 \%$ 첨가 쿠키가 $5.60 \pm 0.50$ 점으로 가장 높게 평가되었다. 반면 아사 이베리 분말 $8 \%$ 첨가 쿠키가 $3.33 \pm 0.61$ 점으로 가장 낮게 평가되었고 아사이베리 분말의 고유한 색이 진하게 나타나 기 때문이라고 사료된다. 아사이베리 분말 첨가량에 따라 서는 아사이베리 분말 $8 \%$ 첨가 쿠키를 제외하고는 색깔에 있어서 대조군보다 다른 첨가군이 높게 평가를 받았으며 유의적인 차이를 보였다( $\mathrm{p}<0.05)$. 아사이베리를 이용한 다 른 연구를 살펴보면 아사이베리 분말을 첨가한 주악(33) 연구에서는 대조군에 비해 아사이베리 분말 $5 \%$ 첨가군이 색깔의 관능평가가 가장 높게 나타난 것으로 보고되었다.

맛(taste)에 있어서 아사이베리 분말 $6 \%$ 첨가 쿠키가 $5.53 \pm 0.51$ 로 가장 좋게 평가되었고 아사이베리 분말 $8 \%$ 첨가 쿠키를 제외하고는 대조군보다 좋게 평가되었으며 아사이베리 분말 $6 \%$ 첨가 쿠키가 대조군과 유의적인 차이 를 보였다(p<0.05). 아사이베리 분말을 첨가한 주악(33) 연 구에서는 아사이베리 분말 $5 \%$ 첨가군이 맛의 관능 평가에 서 가장 높게 평가되었다.

향기(flavor)의 경우 대조군과 아사이베리 분말 $2 \%$ 첨가 한 쿠키와 $4 \%$ 첨가한 쿠키의 경우는 유의적인 차이를 보이 지 않았으며 아사이베리 분말 $6 \%$ 첨가 쿠키가 $5.53 \pm 0.51$ 로 가장 좋게 평가되었다. 반면 아사이베리 분말 $8 \%$ 첨가 쿠키 는 $3.00 \pm 0.13$ 로 가장 낮게 평가되었으며 이는 아사이베리 분말 향기 때문이라고 사료된다.

조직감(texture)의 경우 아사이베리 분말 $6 \%$ 첨가 쿠키가 $5.27 \pm 0.70$ 점으로 가장 좋게 평가되었고 아사이베리 분말 $8 \%$ 첨가 쿠키가 $3.40 \pm 0.24$ 로 가장 낮게 평가되었다. 아사이 베리 분말 첨가량에 따라서는 대조군과 아사이베리 $8 \%$ 첨가 쿠키를 제외하고는 유의적인 차이를 보이지 않았다 $(\mathrm{p}<0.05)$.

전체적인 기호도(overall acceptability)의 경우는 대조군 이 $4.33 \pm 0.97$ 점으로 평가되었고 아사이베리 분말 $4 \%$ 까지 첨가한 쿠키와는 유의적이지 않게 평가되었다( $\mathrm{p}<0.05)$. 아 사이베리 분말 $6 \%$ 첨가 쿠키가 $5.67 \pm 0.61$ 점으로 가장 높게 아사이베리 분말 $8 \%$ 첨가 쿠키가 $3.73 \pm 0.88$ 로 가장 낮게 
평가되었다.

아사이베리 분말 쿠키의 관능 평가 결과 아사이베리 분 말을 첨가한 경우 아사이베리 분말 $6 \%$ 첨가 쿠키의 경우가 대조군과 유의적인 차이를 보이며 색깔, 맛, 향기, 전반적인 기호도 항목에서 높게 평가되어 가장 바람직한 아사이베리 분말 쿠키라고 사료된다.

Table 6. The sensory quality of cookies added with acaiberry (Euterpe oleracea Mart.) powder

\begin{tabular}{cccccc}
\hline Sample $^{1)}$ & Color & Taste & Flavor & Texture & $\begin{array}{c}\text { Overall } \\
\text { acceptability }\end{array}$ \\
\hline $0 \%$ & $4.07 \pm 0.59^{\mathrm{c} 122)}$ & $4.27 \pm 0.79^{\mathrm{b}}$ & $4.53 \pm 0.91^{\mathrm{b}}$ & $4.73 \pm 0.03^{\mathrm{a}}$ & $4.33 \pm 0.47^{\mathrm{b}}$ \\
$2 \%$ & $4.80 \pm 0.67^{\mathrm{b}}$ & $4.60 \pm 0.50^{\mathrm{b}}$ & $4.57 \pm 0.67^{\mathrm{b}}$ & $4.73 \pm 0.70^{\mathrm{a}}$ & $4.47 \pm 0.34^{\mathrm{b}}$ \\
$4 \%$ & $5.00 \pm 0.37^{\mathrm{b}}$ & $4.60 \pm 0.51^{\mathrm{b}}$ & $4.87 \pm 0.51^{\mathrm{b}}$ & $4.80 \pm 0.77^{\mathrm{a}}$ & $4.93 \pm 0.20^{\mathrm{b}}$ \\
$6 \%$ & $5.60 \pm 0.50^{\mathrm{a}}$ & $5.53 \pm 0.51^{\mathrm{a}}$ & $5.53 \pm 0.51^{\mathrm{a}}$ & $5.27 \pm 0.70^{\mathrm{a}}$ & $5.67 \pm 0.61^{\mathrm{a}}$ \\
$8 \%$ & $3.33 \pm 0.61^{\mathrm{d}}$ & $3.07 \pm 1.16^{\mathrm{c}}$ & $3.00 \pm 0.13^{\mathrm{c}}$ & $3.40 \pm 0.24^{\mathrm{b}}$ & $3.73 \pm 0.18^{\mathrm{c}}$ \\
\hline
\end{tabular}

${ }^{1)}$ Values are mean \pm SD

${ }^{2}$ The same superscripts in a column are not significantly different each other at $p<0.05$

\section{요 약}

본 연구는 최근 건강에 대한 관심의 고조로 인해 아사이 베리에 대한 관심이 증가되고 있어 다양한 생리적 효능과 영양학적 특성이 우수한 아사이베리의 실제적인 활용방안 을 모색하기 위한 일환으로 기능성 효과를 가진 아사이베리 분말을 $0 \%, 2 \%, 4 \%, 6 \%, 8 \%$ 배합비율로 첨가하여 쿠키를 제조한 후 품질 특성을 살펴보고 최적의 첨가량을 살펴본 결과가 다음과 같다. 아사이베리 분말 쿠키의 수분함량은 아사이베리 분말의 첨가량이 증가함에 따라 수분함량은 증가하는 경향을 보였으나 유의적인 차이는 나타나지 않았 다 $(\mathrm{p}<0.05)$. 아사이베리 분말 쿠키의 $\mathrm{pH}$ 는 아사이베리 분말 첨가량이 증가함에 따라 유의적으로 감소하는 경향을 보였 다 $(\mathrm{p}<0.05)$. 아사이베리 분말 쿠키의 퍼짐성은 아사이베리 분말 첨가량에 따라 퍼짐성은 유의적으로 감소하는 경향을 보였다( $\mathrm{p}<0.05)$. 아사이베리 분말 쿠키 색도에 있어 명도의 경우 대조군에 비해 아사이베리 분말을 첨가할수록 명도는 유의적으로 감소하는 경향을 보였으며 아사이베리 분말 첨가량이 증가함에 따라 적색도의 경우 증가하는 경향이 나타났고, 황색도의 경우는 감소하는 경향을 보였다.

아사이베리 분말 쿠키 경도는 아사이베리 분말의 첨가량 이 증가함에 따라 경도의 값이 유의적으로 증가하는 경향을 보였다(p<0.05). 아사이베리 분말 쿠키의 관능 평가에 있어 색깔(color), 맛(taste), 향기(flavor), 조직감(texture), 전체적 인 기호도(overall acceptability) 항목에 있어서 대조군에 비 해 아사이베리 분말 $6 \%$ 첨가 쿠키가 가장 높게 평가되었다.

\section{References}

1. Park DS (2007) Plans of Improving the Competitiveness of the Korean Health Food Industries. MS Thesis, Kyungpook National University, Daegu, Korea, p 1-4

2. Hwang IK (2007) Survey on metropolitan middle-aged men's perception and consumption pattern of health/ functional foods. MS Thesis, Yonsei University, Seoul, Korea, p 1-36

3. Lee YM, Lee KY, Jang HK (1996) Eating out behaviors and attitude toward Korean foods in adult. Korean Society Food Culture, 11, 317-326

4. Heo C, Kim NY, Kim HP, Heo MY (2005) Anti-oxidant activity of vegetables or fruits extract in mice. Yakhak Hoeji, 49, 243-250

5. Yoon JM, Hahn TR, Yoon HH (1998) Effect of Copigmentation on the stability of anthocyanins from a Korean pigmentied rice variety. Korean J Soc Food Sci Technol, 30, 733-738

6. No SW (2008) Effect of anthocyanin obtained from wild grapes on the photooxidation stability of soy milk. MS Thesis, Dankook University, Seoul, Korea, p 1-8

7. Kang HH (2009) Determination of biological activities of Korean berries and their anthocyanin identification. MS thesis, Gyeongsang University, Jinju, Korea, p 3-7, 32-59

8. Kim HS (2012) Quality characteristics and anti-oxidant activities of muffins with the acai berry (Euterpe oleracea Mart.) powder. MS thesis, Sejong University, Seoul, Korea, p 1-49

9. Jie Kang, Zhimin Li, Tong Wu, Gitte S. Jensen, Alexander G. Schauss, Xianli Wu (2010) Anti-oxidant capacities of flavonoids compounds isolated from acai pulp. Food Chem, 122, 610-617

10. Marcason W (2009) What is the acai berry and there health benefit. J Am Diet Assoc, 109, 1968-1973

11. Gitte S, Jensen (2008) In vitro and in vivo anti-oxidant and anti-inflammatory capacities of an anti-oxidant-rich fruit and berry juice blend. Results of a pilot and ranomized, doubled-blinded, placebo-controlled, crossover study. J Agric Food Chem, 56, 8326-8333

12. Heinrich M, Dhanji T, Casselman I (2011) Acai a phytochemical and pham cological assessment of the species' health claims. Phytochem Lett, 4, 10-21

13. Veridiana Vera de Rosso, Silke Hillebrand, Elyana Cuevas Montilla, Florida O. Bobbio, Peter Winterhalter, Adriana Z. Mercadnte (2008) Determination of 
anthocyanins from acerola and acai by HPLC-PDAMS/MS. J Food Comp Anal, 21, 291-299

14. Knekt P, Jarvinen R, Reunanen A, Maatela J (1996) Flavonoid intake and coronary mortality in Finland : a cohort study. Br Med J, 312, 478-481

15. Lee SJ, Yang JA, Choi JH, Kim KY, Hong HJ (1999) Quality characteristics of Seolggiddeok added with green tea powder. Korean J Food Cookery Sci, 15, 224-230

16. Lee JH, Park JR, Chun SS (2001) Effects of pine pollen powder on the quality of white bread prepared with Korean domestic wheat flour. Korean J Food Nutr, 14, 399-345

17. Ahn JM, Song YS (1999) Physicochemical and sensory characteristics of cakes added sea mustard and sea tangle powder. J Korean Soc Food Sci Nutr, 28, 534-541

18. Park YK, Kang YH, Lee BW, Seong HM (1997) Changes of carotenoids of the pumpkin powder during storage. J Korean Soc Food Sci Nutr, 26, 32-36

19. Jeong SY, Jeong SH, Kim HJ, Kim MR (2002) Sensory characteristics of functional muffin prepared with ferulic acid p-hydroxybenzoic acid. Korean J Soc Food Cookery Sci, 18, 476-487

20. Lee JH, Ko JC (2009) Physicochemical properties of cookies incorporated with strawberry powder. Food Eng Prog, 13, 79-84

21. Kim YA (2008) Effects of strawberry powders on the quality characteristics of yellow layer cake. J Food Cookery Sci, 24, 536-541

22. Yu OK, Kim JE, Cha YS (2008) The quality characteristics of jelly added with Bokbunja (Rubus coreanus Miquel). J Korean Soc Food Sci Nutr, 37, 792-797

23. Yu OK, Back HI, Cha YS (2008) The quality characteristics of pudding added with Bokbunja (Rubus coreanus Miquel) fruit juice and Bokbunja wine. Korean J Dietary Culture, 23, 616-620

24. Park GS, Lee JA, Shin YJ (2008) Quality characteristics of cookie made with oddi powder. J East Asian Soc Dietary Life, 18, 1014-1021

25. Park BH, Cho HS, Park SY (2005) A study on the antioxidative effect and quality characteristics of cookies made with lycii fructus powder. Korean J Food Cookery, 21, 94-102
26. Joo NM, Kim SJ (2010) Optimizing production conditions of germinated brown rice cookie prepared with beet powder. J Korean Diet Assoc, 16, 332-340

27. Kim BR, Joo NM (2010) Optimization of brown rice cookies using purple sweet potato. J Korean Diet Assoc, 16, 341-352

28. Bae HJ, Lee HY, Lee JH, Lee JH (2010) Effect of saururus chinensis powder addition on the quality of sugar snap cookies. Food Eng Prog, 14, 256-262

29. Kim SK, Choi YS(2013) The quality characteristics of rice cookies added with Guava (Psidium guaja va L.) powder. Korean J Culinary Res, 19, 248-258

30. Ko HC (2010) Quality characteristics of sugar snapcookie with added cornus fructus. J East Asian Soc Dietary Life, 20, 957-962

31. Ji JR, Yoo SS (2010) Quality characteristics of cookies with varied concentrations of blueberry powder. J East Asian Soc Dietary Life, 20, 433-438

32. Kang SH (2013) Effect of acai berry (Euterpe oleracea Mart.) on shelf-life and quality characteristics of wet noddle. MS Thesis, Catholic University, Korea, 3-7

33. Hwang SY (2013) Physiochemical and physical characteristics of Juak with acai berry (Euterpe oleracea Mart.). MS Thesis, Catholic University, Korea, 1-3, 21-39

34. Han JY (2013) Processing optimization and quality characteristics of Gwapyeon prepared with acaiberry (Euterpe oleracea Mart.). MS Thesis, Sookmyung University, Seoul, Korea, 4-6

35. Lee SY (2010) Partially purified Euterpe oleracea Mart. decreases melanogenesis via ERK activation and subsequent down regulation of MITF. MS thesis, Kyunghee University, Seoul, Korea, 9-11

36. Jung KJ, Lee SJ (2011) Quality characteristics of rice cookies prepared with sea mustard (Undaria pinnatifida Suringer) powder. J Korean Soc Food Sci Nutr, 40, 1453-1459

37. AACC (2000) Approved methods of the AACC. $10^{\text {th }}$ ed. Method 10-50D. American Association Cereal Chemists, St. Paul, MN, USA

(접수 2014년 5월 29일 수정 2014년 8월 7일 채택 2014년 8월 14일) 